\title{
Earth Forces
}

\section{Contemporary Land Arts, Technology and \\ New Materialist Aesthetics}

\begin{tabular}{c} 
JUSSI PARIKKA \\
WINCHESTER SCHOOL OF ART/UNIVERSITY OF \\
SOUTHAMPTON \\
\hline
\end{tabular}

In fact, the Earth speaks to us in terms of forces, bonds, and interactions, and that's enough to make a contract. Each of the partners in symbiosis thus owes, by rights, life to the other, on pain of death.

Michel Serres ${ }^{1}$

\section{-INTRODUCTION}

There are more interesting aspects to the term posthuman than mere talk about the end of the human. Indeed, in recent new materialist philosophy two approaches that stem from a Deleuzian background both suggest a problematisation of the term 'post'. Brian Massumi, in What Animals Teach us About Politics, argues for a route

Cultural Studies Review 2015. ( 2015 Jussi Parikka. This is an Open Access article distributed under the terms of the Creative Commons Attribution 4.0 Unported (CC BY 4.0) License

(https://creativecommons.org/licenses/by/4.0/), allowing third parties to copy and redistribute the material in any medium or format and to remix, transform, and build upon the material for any purpose, even commercially, provided the original work is properly cited and states its license. 
that abandons the temporally too linear talk about the end of the human. Instead, consistent with an ontological stance towards the continuities across the animalhuman continuum, he reminds us that any talk of the posthuman would have had to anyway already tell us what the human is or was. Hence, the 'more-than-human' becomes a preferred term for Massumi. ${ }^{2}$ His aim is to address the middle of the various terms that offer typological differences, although in material reality offer only differences in intensities. ${ }^{3}$ In other words, the task becomes to think of materiality through those differences in intensities. Indeed, Massumi finds an ally in Judith Butler, whose words he quotes when referring to the need to find the point where 'typological thinking falls apart'.4 It is this insistence on regimes of reality other than (merely) typological naming that is able to track the constantly morethan-human that defines and sustains the human.

In her approach, Rosi Braidotti sticks with the term posthuman. She tracks the possibility of finding non-linguistic regimes through which to develop immanent relations with the material reality that is not defined through the primacy of the human as a cognitive or sensing entity. Against the regulatory historical framework of Man, the notion of the posthuman is a placeholder for a different set of concepts, one that foregrounds alternatives to anthropocentric formations. ${ }^{5}$ Despite using the term posthuman, Braidotti's take focuses on the Deleuzian a-personal life, the notion of the nonhuman that stems from a Foucault-Deleuze set of antihumanism and a wider appreciation of the primacy of relations as an ethical stance allowing the development of ontogenic, transversal ties across species in ways that refer to Donna Haraway's work as much as to a Spinozian ontology. For Braidotti, the notion of the posthuman becomes a convenient way to place this sort of subjectivity in a camp that is neither postmodern (the posthuman is not anti-foundationalist), nor poststructural (for Braidotti, the posthuman is not based on frameworks of language). Rather, this is a new materialist, embedded and located subjectivity that does not draw so much on the celebration of the nonhuman of certain sorts of speculative realism, but on culturally and historically situated formations of modes of life that are irreducible to the human being. ${ }^{6}$ Indeed, the notion of materiality of matter that is real, becomes an ethical stance. As Braidotti insists: 'Far from being a flight from the real, posthuman thought inscribes the contemporary subject in the same conditions of its own historicity. ${ }^{7}$ 
In both Massumi's and Braidotti's accounts, and more broadly as part of the thrust of animal studies, the displacement of the subject returns a focus to animal realities or the wider forces of the zoe. ${ }^{8}$ In a way, this points to a complementary set of questions and concepts to that of the biopolitical. For Massumi, the question is less about the subject and subjectivity than about conceptualising the territories, intensities and relations in which the more-than-human happens. Hence, animal politics becomes a 'lesson' in the 'relational techniques of lived abstraction', a key term for Massumi who links it to the virtual in the Deleuzian sense. ${ }^{9}$ It marks the lived experience as a potentiality that does not refer to the actual embodiment based on subject-object relations. Instead, terms such as inter-givenness are used by Massumi to highlight the co-determining primacy of the relation in which experience becomes and is defined by its potentiality. The conceptualisation of 'abstraction' relates to Whitehead in the sense of not referring only to the mental abstraction that pertains to the particular cognitive capacities of the human, but also to the expression of 'nature's mode of interaction'.10

Several of the new materialist theories have a commitment to ontology of relationality. They also articulate new conceptualisations of posthuman life in contemporary capitalism that work by capture and use of regimes of the nonhuman. One could say that the Guattarian impulse to aesthetico-ethically invent new forms of experimental living becomes a Spinozian ethical stance that strives to map, for example, animal intensities as such 'teachings' in new materialist living that are of relevance to the themes of this special section of Cultural Studies Review. It is also, however, the non-organic sphere that one is able to draw on as part of this theorisation-surprisingly neglected, even if briefly mentioned in some accounts such as Jane Bennett's and Braidotti's references to geocentric perspectives. ${ }^{11}$ In other words, the aim of this essay is to find the points of conjunction between some contemporary technological art practices and new materialist theory and, by way of this cross-talk, to find elements which contribute to new materialist aesthetics. The aim is not to create a unifying theory of 'new materialist aesthetics' but under that notion to carve out some useful themes in terms of these art practices and how their art methods elaborate an implicit understanding of sensation and perception that pertain to the connection between technological culture and geophysics. The position of this article is especially relevant in its connection to animal studies and 
the recent turn to non-organic life-or, one could even say, non-organic aestheticsthat carves out the aesthetic qualities of dynamic planetary matter: what is sensation, perception and affect in relation to the nonhuman earth? My primary intention is less about offering a particular art historical reading, even if one section discusses themes of interest to scholars of Modernist visual arts as well as art and ecology. The art historical context of Robert Smithson and others does, however, offer a way to pick up some threads that offer a specific way of understanding some contemporary media art practices from the perspective of land art. I also want to show how this perspective feeds into the issue of new materialist aesthetics of geologically attuned media culture. As the discussion below will address, one of the issues that arises from involving the geological and the non-organic is how, in artistic practices, questions of personal experience are bracketed in favour of experiments that offer an ontological and aesthetic vocabulary. 12

Hence, it is my aim to provide a variation on the themes that Massumi, Braidotti and others offer towards issues in geology and aesthetics, and to encourage such Guattarian experimental aesthetico-ethical relations and ways to discover the morethan-human and the nonhuman in aesthetic relations pertaining to new forms of land art. In this manner, one could brand the question of this article as 'what geology teaches us about politics?' This question seems tongue-in-cheek way of rephrasing of Massumi, but becomes clearer when looking at a range of art practices set in the context of the Anthropocene. Indeed, one can say of the practices and projects analysed in this essay that they offer, in Mitchell Whitelaw's phrase, 'both practical specificity and speculative reach'.13

\section{-Geological ARTS AND TIME-FORCE}

The Anthropocene is, of course, not something to be taken at face value. It is definitely one key reference for discussions on the posthuman, climate change and the wider context in which geological eras meet questions of design; the debate has followed on from the geological and climate science discussions of the past ten to fifteen years and even forerunners to this in the nineteenth century (I am here thinking of Antonio Stoppani and George P. Marsh). However, the debate has mostly revolved around the impact of human involvement in geological formations to the extent it deserves to be named a specific era. As Donna Haraway points out, the 
concept should be read in relation to a range of companion concepts such as the Capitalocene and the Chthulucene. ${ }^{14}$

In some ways, one feels that the merits of the discussions around the Anthropocene have indirectly spurred a range of artistic, curatorial and theoretical work that has significantly addressed the entanglement of aesthetics, epistemology and questions of governance. ${ }^{15}$ What is interesting about these various activities is that they often fulfill a rather archaeological and historical function in referring to various earlier phases in which human impact was addressed by aesthetic means to understand its relation to the earth. Indeed, as important predecessors, one could speak of the originating earth/land art of the 1960s, the emergence of the ecological movement and 1970s environmental arts, the green politics of the 1980s and exhibitions such as 'Fragile Ecologies' held in 1992 in New York. Similarly, the mid2000s Sustainable Art practice in New York and the Eyebeam scene can be cited as an important context for some artists. ${ }^{16}$

Eleanor Heartney talks of the influences of earlier artists:

But current projects build on a firm foundation of work by pioneers like lan Sonfist, Helen Mayer Harrison and Newton Harrison, Agnes Denes and Mierle Laderman Ukeles, several of whom were included in 'Dark Optimism'. In the 1970s, these artists were already examining the ramifications of humanity's impact on the environment in works that encompass the transformation of landfills into parks, the restoration of sections of the urban grid to their presettlement state and the mapping out of ambitious plans for the natural and industrial restructuring of endangered watersheds. ${ }^{17}$

But it is indeed already in land art-or earth works-emerging in the 1960s that one finds a significant investment in the articulation of the earth as part of the aesthetics of contemporary art. ${ }^{18}$ Such aesthetic practices become investigations concerning a relation with earth and its radical temporality; they refer to a situation of human involvement with the planetary and the irreducibility of the earth to its human inhabitants. It is significant that land art emerges after World War II; the dates identified recently as key to the Anthropocene era are the start of the nuclear (explosion) age and the Great Acceleration produced by a massive number of interlinked chemical, technological, economic, lifestyle and general biotic 
changes ${ }^{19}$-as a broader environmental consciousness that was part of the emergence of earth works although the actual term Anthropocene came later.

Land art is often referred to as being inaugurated in the 1968 New York exhibition titled Earth Works, which featured many of the key names. Indeed, it is most clearly in the work of Robert Smithson-various art pieces, writings, film, and so forth-that one can decipher the relation of land art, or earthworks, as a detachment from some key themes in modernism as well as a detachment from the gallery as the specific site of modernist art. The expansion of the site of art to the outdoor space is, besides a refusal of the distance-taking gaze of landscapes, also an acknowledgement of the extended materialities in which art-making is employed.20 The framework of art in works such as Smithson's was an investigation of aesthetic expression as well as an epistemological commentary that also reflects a media historical side to the issue: the use of film, Geiger counters and other measurement technologies that becomes instrumental in knowledge of the earth and defines a specific media historical situation of the Cold War era, when a lot of land art encountered the earth. ${ }^{21}$ This was also a period when new sites and techniques of the artist where negotiated, with the emphasis gradually moving from crafts to more industrial techniques and technology.22

Smithson's writings, such as 'A Sedimentation of the Mind' from 1968, could in many places be read as a parallel to Gregory Bateson's work on ecological thought and even the later follow-ups by, for example, Guattari. Bateson's 'ecology of mind' grounds significant parts of Guattari's ecological way of approaching the sedimentation of global capitalism, social relations and psychic reality, and one can find a similar potential cultivated in Smithson's work. ${ }^{23}$ It has potential as an aesthetico-material media theory from the onset as it distances itself from the prosthesis-driven media arguments of Marshall McLuhan. Smithson's more chemical take argues that media are not anthropomorphic extensions of Man but aggregates of elements, a statement which one can see in a philosophical but also material sense: media are derived from the chemical elements that form the geological earth. ${ }^{24}$

The work of the artist becomes here akin to that of an archaeologist, or even a geologist, investigating the materials that extend further than to technology. Smithson's idea of the experimenting artist is not merely about experiments with 
artistic genre in the avant-garde fashion. In a more metallurgical sense, this experimentation revolves around what constitutes technology and the aesthetic object. Geological material itself becomes a way to track the mutant transformations, a transversal method of continuum across the material and the linguistic (which are not, in fact, two separate spheres). Instead of a clear-cut poststructuralist ontology based in language, we discover the terminology of geology embedded in this way of understanding the nature of the material:

The names of minerals and the minerals themselves do not differ from each other, because at the bottom of the material and the print is the beginning of an abysmal number of fissures. Words and rocks contain a language that follows a syntax of splits and ruptures. Look at any word long enough and you will see it open up into a series of faults, into a terrain of particles each containing its void. ${ }^{25}$

Despite the usual description of Smithson as a dialectical materialist, I find more interesting his references to methodological following of material as the line that crosses through the usually discrete distinctions key to an art vocabulary. ${ }^{26}$ Thought, the brain, aesthetic material and the earth become involved in joint assemblages that are defined by this movement:

Separate 'things', 'forms', 'objects', 'shapes', etc., with beginnings and endings are mere convenient fictions: there is only an uncertain disintegrating order that transcends the limits of rational separations. The fictions erected in the eroding time stream are apt to be swamped at any moment. The brain itself resembles an eroded rock from which ideas and ideals leak. ${ }^{27}$

It would be possible to focus on Smithson's aesthetic geology itself, which also relates to the philosophical figure of the metallurgist, introduced by Deleuze and Guattari in A Thousand Plateaus and employed recently in Vibrant Matter by Jane Bennett. ${ }^{28}$ The concept of the metallurgist refers to a different practice-based epistemology that proceeds by way of sensitivity to the material at hand without aiming to extract constants-unlike 'royal science', the dominant form of analytical knowledge. Instead, metallurgy is a figure of knowledge that is interested in the primacy of variation as a way of understanding and tapping into the characteristics of the materials; the 'singularities or spatiotemporal haecceities of different orders 
and the operations associated with them as processes of deformation or transformation'.29 In other words, as a form of nomadic practice and knowledge (the theme of nomadism connects it also to Braidotti's project), it is interested in the potential for transformation, corporeality of change and different ways of engaging in codetermining relations with the ontogenetically mutating world. Or, in short, in following the matter-flow to understand its qualities. ${ }^{30}$ This also relates to the themes addressed in the article by Tiainen, Kontturi and Hongisto in this special section.

The notions of time in Smithson's project are another interesting way of describing it not as a substance-based aesthetic ontology but as one that works through the dynamics of erosion, entropy and the radical openness of time. This aesthetics cuts through, again, the levels of the brain and the geological. In new materialist philosophy, this has primarily been worked through the relation of Darwin, Bergson and the emerging philosophical basis of the theory of evolution. Elizabeth Grosz's work, for example, is in this sense instrumental as a new materialism based on a radical ontology of time. ${ }^{31}$ But we can appreciate the similar thrust that one finds in aesthetics interested in the dynamics of non-organic life and the multiplicity of times that work in the long-term scale and also becoming-other, of life overcoming 'itself through its activities' that transform its objects, from species to individuals, as Grosz puts it. ${ }^{32}$ This transformational quality of time as force is also important when considering the nonhuman centres of gravity that affect the situations of the non-organic and technological. ${ }^{33}$ In a related manner, Simon O'Sullivan expands on Smithson's idea of geoaesthetics, as a specific planetary materiality that unfolds through a new notion of time emerging from Smithson's interest in materials of modernity such as plastic, chrome and electric light. This energises 'the new monument' (Smithson's term) which according to O'Sullivan is also related to a new image of time. ${ }^{34}$

I will continue the line of thought proposed by this article about new materialist aesthetics with references to more technological art practices. These continue some of the themes we find in earlier earthworks and Smithson's work. This mapping of current media arts practices and projects allows us to find an insightful relation to contemporary aesthetics of matter that is executed in relation to the important questions of software and, broadly, technology. Doing so highlights 
a different way of understanding land, earth or even territory. Besides connecting this understanding to discussions in new materialist aesthetics, it becomes a way of engaging in practices of digital art different from the usual focus on software and visuality. 35

\section{-THE COMPUTATIONAL PLANET}

Smithson's notion of abstract geology captures the dynamics of geology as one that also pertains to other strata of reality. ${ }^{36}$ The geological becomes detached from the earth and a marker of the material dynamics, a temporal change, radical due to its persistent slowness, always localisable and yet expressive in planetary ways. Abstract geology is not only abstract for the human cognitive sphere of the mind but perhaps also more Whiteheadian in the sense briefly mentioned above through Massumi: the world itself includes abstraction. Abstraction is what links mental processes to geology and also to the regime of perception and sensation. Abstract geology can also thus be expressed through art practices and discourses that connect art with the theoretical work of new materialism. Abstract geology persists even in the techno-economic themes of 'mining' data, where the promises of massive Big Data sets are directly linked to monetary value creation through different mechanisms in tracking consumption patterns, societal trends and so on. ${ }^{37}$

When focusing on art practices, aesthetic objects-that is, objects that are part of the mediation of sensation and perception-become understood through their strata, minerals and the qualities that pertain to them. This is a sort of geology of the aesthetic object:

In these rocks one might find: actinolite, albite, allanite, analcime, apatite, anhydrite, apophyllite, aurichalcite, aximite, azurite, babingonite, bornite, barite, calcite, chabzie, chalcocite, chalcophyrite, cholorite, chrysocolia, copper, covellite, cuprite, datolite, epidote, galena, glauberite, goethite, gmelinite, greenockite, gypsym, hematite, heaulandite, hornlende, laumontite, malachite, mesolite, natrolite, opal, orpiment, orthoclase, pectolite, prehnite, pumpellyite, pyrite, pyrolusite, quartz, scolecite, siderite, silver, sphalerite, sphene, stevensite, stilbite, stilpnomelane, talc, thaumasite, thomsonite, tourmaline, ulexite. ${ }^{38}$ 
As Etienne Turpin argues, Smithson's artistic practice and writings demonstrate a distancing from the Greenbergian tone of modernist aesthetics, with its demand for medium-specificity (not to be confused with the discussions of medium-specificity in recent media theory). Instead, the surprising aesthetico-political stance in Smithson becomes 'a demand for artists and thinkers today to confront, through inhabitation and apprenticeship, the disorienting material spiral of mineralization' ${ }^{39}$ This is a position that Turpin connects also to the current Anthropocene discussions. In any case, what in Smithson's work still refers to the practices of land art and visual arts is mobilised in more recent work by, for example, Martin Howse, Jonathan Kemp and Ryan Jordan into an alchemic mix of approaching computer culture through a similar apprenticeship in mineral qualities.

Especially in their The Crystal World project and exhibitions, Howse, Kemp and Jordan have engaged with the mineral qualities of computational culture by way of a lineage other than computational aesthetics. Instead of focusing on a computer graphics-oriented visual art, their work has addressed the material qualities that enable computationality to exist. They have exhibited different installations of computational hardware that had been exposed to chemical reactions: motherboards and other technological components meet a DIY laboratory sort of a setting; earth materials brought into contact with principles of computation. For example, the Earth Computer is: 'Two thick lengths of copper lead into a tray set into a bed of mud, the tray containing lumps of scavenged copper and zinc in a solution of silver nitrate.' 40

Parallel to the way earthworks projects moved the emphasis of modern visual arts from the gallery to outdoors, from art object to processual practice including workshops with outsider participants and engagement with new materials that recognised the impact of technological culture, such recent art methods shift the focus from the screen and even the algorithmic to the materials on which computationality runs. ${ }^{41}$ In different iterations of the Crystal World project in 2011 and 2012 in Berlin and the United Kingdom, Kemp, Howse and Jordan aimed to engage with participants in methods, assays and experiments to reveal the crystal basis of computationality.

The Crystal World experimental research works through various decrystallizations of the digital, returning to the earth redundant 
electronics, the poisonous support for a synthesized dystopic world, the pure mineral. Mimicking the often dangerous processes undertaken in the recovery of rare and precious metals by the dispossessed, the Crystal World proposes to expand these world interventions through experimentation in the formation of novel crystal geologies aimed to etch unexpected psychophysical distortions and contingencies into our contemporary crystalline cycles. ${ }^{42}$

The projects' various methods engage with the chemical basis of digital culture. The crystal is adopted as the key conceptual ground through which the metal/mineral basis of the digital machines is excavated both in terms of their material and their global logistics, which ensures supply chains of critical materials. This sort of computational earth aesthetics becomes a way of deterritorialising the computational from a corporate packaged assemblage into a variety of computational processes at large. The art methodology of such earthworks could be seen as a version of psychogeophysics, an extended version of psychogeography not merely restricted to the urban geography but tackling the wider geophysical situations of planetary computation. ${ }^{43}$ Of course, there are differences in the approach too. The Crystal World and other Earth Media projects of this artistic trio, together and separately, have involved 'found-objects' of earth as media process. Psychogeophysics focuses slightly more on the processes of engaging with the earth, investigating the particular methods and sites where the earth takes place in relation to human experience and aesthetics. In any case, in Kemp, Howse and Jordan's version of 'abstract geology' (a term from Smithson), geology becomes a transversal line that cuts across earth formations, mineral qualities and computational processes much more materially than Stephen Wolfram's cellular automata-inspired view of the universe as based in computational processes.

Howse and Kemp's project descriptions are an interesting combination of situated site-specificity and computation in ways that implicitly address Braidotti's call for a geocentric perspective. From another workshop related to their projects, they say:

Re-situating some of computations processes (etching, leaching, doping) within ruined quarries, slag heaps, and mines, research is centred on the bi-directional parallels between computation, and geological metaphors 
(sedimentation, read write, sort operations), culminating in a set of (auto-

destructive) simple geo-logical process machines. ${ }^{44}$

What is important here is that this way of investigating the planetary materialities is still situated in concrete places as the hotspots of investigations. This is a new materialism of the archaic planet and a new materialism related to art practices too. It does not become a totalised and unsituated view without its own place, but rather a way of crossing across the scales of the local and the planetary. (On this point, see again the article by Hongisto, Kontturi and Tiainen in this issue, addressing Biophilia by Björk.)

Martin Howse continues a similar line of investigation in another project, The Earthcodes, or Earthboot. The project becomes another installation of the earthworks of Smithson and others by way of reterritorialising code into earth matter. The technological system designed by Howse is planned to boot the computer directly from the earth instead of from a disk or a hard drive. It draws on earth electricity and taps into both a speculative design project and a media archaeological idea of the telluric currents of the earth. Leaving aside the specific technological device, a custom-made earth interface hardware, the project engages with the abstract materialities that by necessity energise computing. Howse's Earthcodes proposes bypassing the longer material logistical chains producing standardised computer culture through minerals and other materials, and returning the abstract layers of software into a direct relation with the earth.

The substrate becomes this quasi-mystical, but material, force that plays with the idea of vampiric relation. As Howse describes it on the project page:

earthboot boots from the earth.

earthboot returns vampiric technology to the earth.

earthboot enables almost any computer to boot straight from the earth, sidestepping dirty mining actions, and the expensive refining and doping of raw minerals; thus avoiding environmentally wasteful production techniques for the construction of data bearing devices such as hard drives or USB memory sticks. 


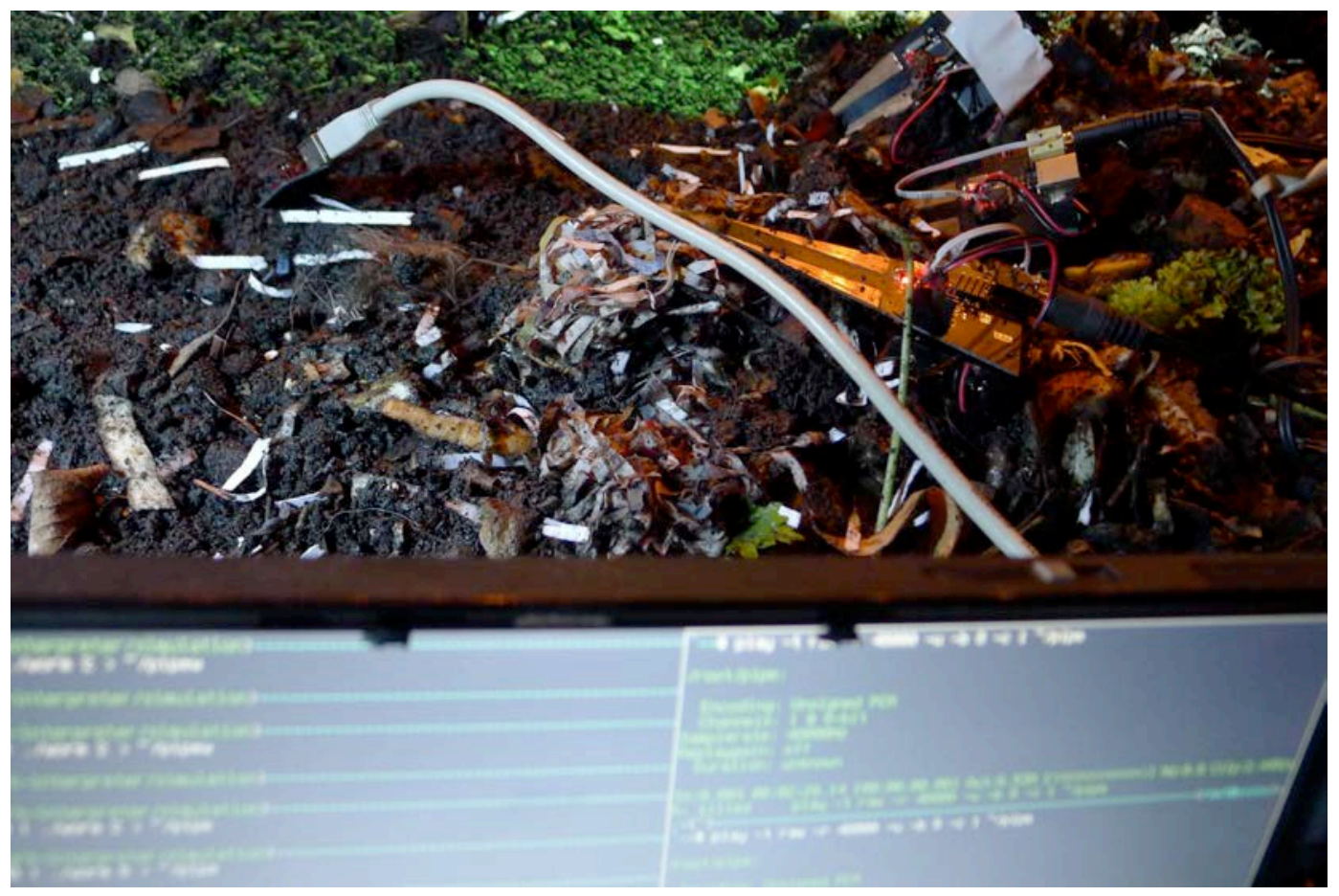

Figure 1: Wormcode, Martin Howse. Used with permission.

Instead, earthboot boots straight from the earth itself, exploring the being-substrate of contemporary digital technology; the material basis of 21st century computation.

earthboot revives the use of underground flows of electricity or telluric currents which were first exploited as generators of power within the telegraphic communications apparatus of the 19th century.

earthboot proposes a barely functional telluric operating system (OS), exposing the vampirism of current technology. Telluric or underground currents are translated directly into code for an earthbound operating system. ${ }^{45}$

Howse's project does not stop at the geological earth as a substance, but approaches it through such assays as a living quasi-organism consisting of different interactions that are energetic and material. This includes interactions of organic and nonorganic, demonstrated in his more recent extension of the project to include worms and worm poetry; to use the device to communicate with worms who could even 'write texts for us' and have those texts sung, recited and 'published as worm poetry'. 46 
There is other recent work that speaks to similar themes of the living earth while refusing to be part of a more nostalgic or New Age type of Gaia-discourseand also refusing the nostalgic orientations of the sustainability discourse. I am thinking here, for instance, of the inspiring work by the Finnish artist Terike Haapoja, whose 2008 work Inhale-Exhale is a durational sculpture. ${ }^{47}$ It engages with the planetary process of the cycle that occurs when carbon travels across the biosphere and the atmosphere. Haapoja's sculpture reminds us that the supposedly geological earth is entwined with the biosphere, the substrate being more than dead matter and more accurately understood through 'soil breathing'. The work's silent atmosphere effectively emits this inhaling and exhaling as a sort of a communication system which for the viewer becomes not merely aural, but also atmospheric, in the installation room.

Keeping in mind Haapoja's work but more especially in the context of Howse, Kemp and Jordan's projects, one could say there is a sense these explorations are trying to address the intensive cycles and transformations of materials of the earth.

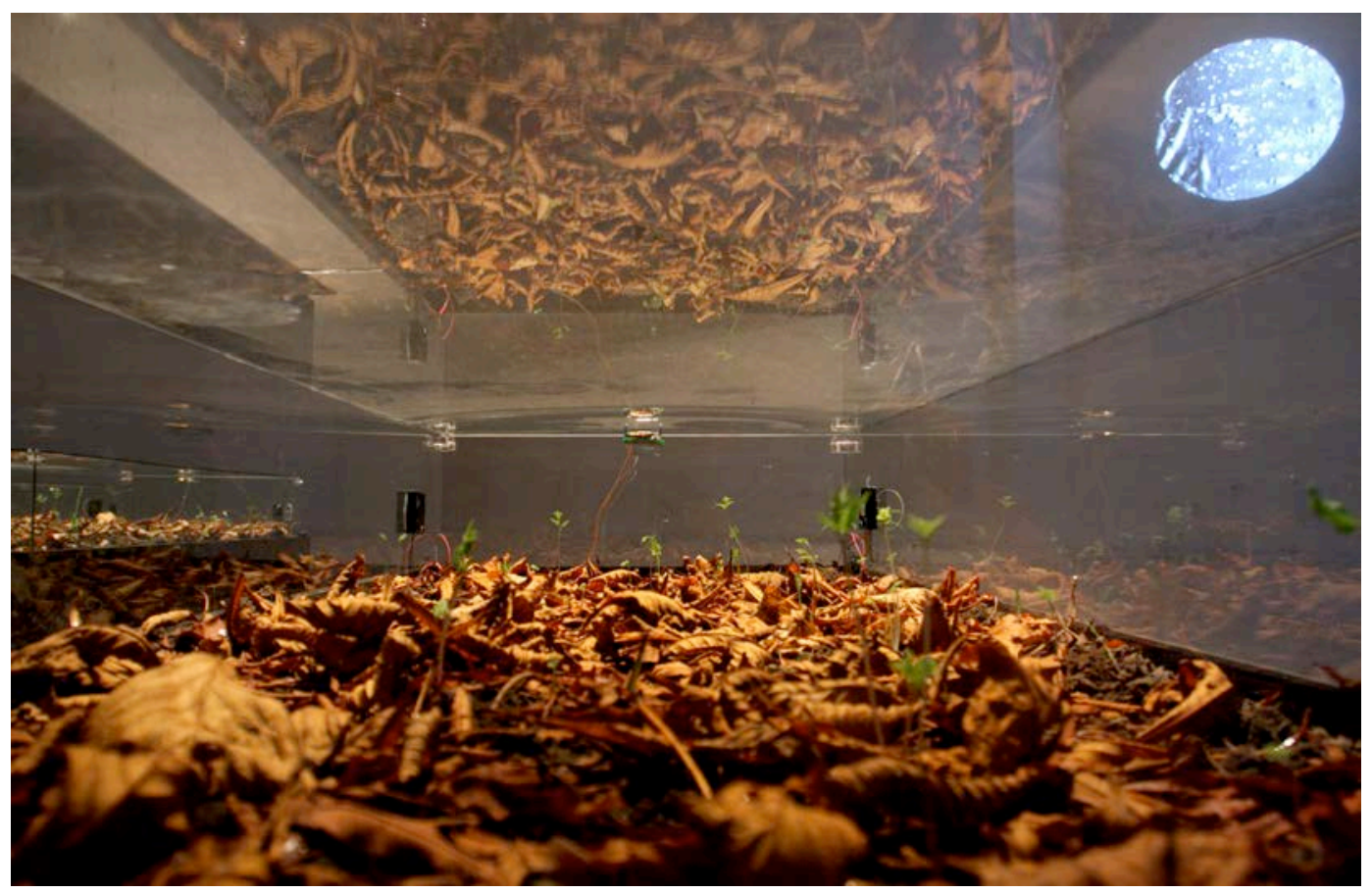

Figure 2: A close-up of Terike Haapoja's INHALE-EXHALE (2008/2013); Durational sculpures, plywood, glass, soil, CO2 sensors, sound). Programming Aleksi Pihkanen, Gregoire Rousseau. Image: Sandra Kantanen, used with permission. 
In Haapoja's work this functions through the use of sensors that modulate the CO2 levels into sound that rhythmically creates a living atmosphere of breathing. In the different sort of new materialist aesthetics of 'sheer hardware' (to use a phrase from Whitelaw that itself draws on Friedrich Kittler) the materiality actually goes beyond hardware; the earth becomes a form of living matter that resonates with Manuel Delanda's notes about the life of the non-organic. ${ }^{48}$ This emphasis is clear across a range of projects, including the curated Pitch Drop program of 'A Slow Media Diet', which was exhibited in Denmark at Science Friction (Copenhagen) and online. ${ }^{49}$ Artists including Howse, Rosemary Lee, Will Schrimshaw, Anders Kølle and Jamie Allen addressed an ethological way to understand media not so much through substances as through their qualities of transformation, speed and slowness. ${ }^{50}$ The exhibition program was articulated as:

a time for the plodding and the thick, the slow and the oozing, the gunk and the cruft. It turns out media technologies are really just fast matter, the highly excited negentropic pushing and pulling of atoms, electrons, signals and pixels. Rocks, stones and minerals, forever examples of inactivity and stillness, are in fact vibrant, dynamic medias for time-space scales unknown. ${ }^{51}$

Geological vocabulary becomes infused here with temporal notions that dynamise the supposedly 'dead' or at least stable formations. As Jamie Allen explains, the works are also often meant quite literally: a slowing down of sound produces an awareness of the speaker; the slowing down of film produces a flicker of awareness about the petroleum plastics of film; digital images when slowed down become striped, pixelated-exposing their material energies. ${ }^{52}$ This sort of slowness as art method lets us understand how matter can turn media, and how media is matter that can be manipulated through speeds, oscillations and energy (frequencies). It is indeed in the scientific assays that an example of artistic and scientific mix is again discovered; the project's exemplary inspiration is the by now famous Professor Thomas Parnell's 1927 inaugurated Pitch Drop experiment, which shows the fluidity of rock material, the becoming-dynamic of geological material:

Pitch rock, as a medium, is placed into a laboratory funnel, continuously 'dripping' out of a funnel for the past 80 years or so. What registers on one level as the Guinness World Records' longest continuously running 
laboratory experiment, calls up the geo-physical origins and nature of all

media, their blinkered disposition toward us as human beings. ${ }^{3}$

Even 'pitch rock' can be seen as media.

The earth becomes understood through the ethological relations in which it expresses potentials through speed, slowness, a temporal materiality. ${ }^{54}$ This temporal perspective troubles too-facile distinctions between the geosphere and the biosphere as different regimes of change. Instead, one understands how things are interlocked. And instead, in a way that resonates with Deleuze and Guattari's understanding of the geological, the geosphere becomes an indicator of the machinic phylum that cuts across the different spheres of matter as well as becoming indicative of how life moves 'beyond itself into the very reaches of the inorganic', 55 to use Grosz's words. It is in this context of the temporality of matter that Grosz works through Deleuze, Darwin and especially Bergson to make it clear we should not restrict notions of the inorganic, geological and, one might add, technological, to the spatial. Indeed, this would, as Grosz points out, 'reduce the material to the geometric, to the mechanical',56 thus stabilising something which at the very onset was dynamic in its geophysical force, a metallurgical force.

-THE INFRASTRUCTURAL

Such artistic projects summon new ways of understanding land art as a computational, planetary project and present ideas for a new materialist aesthetics. Read beside the philosophical works of Massumi, Braidotti, Grosz and others, the art projects discussed above become philosophical investigations executed by speculative practice. The material practices, experiments and aesthetics addressing an ontological sphere of materiality extending into a dynamic temporal structuring are continued in Jamie Allen's projects. As part of the Transmediale 2013-14 residency project, Allen, with David Gauthier, addressed 'Critical Infrastructures', signalling a shift from the vocabulary of critical theory to 'media archeology of the present'.57 The project, which also produced a major installation as part of the transmediale festival's main venue at Haus der Kulturen der Welt (HKW) in January-February 2014, thus continued the work of experimental media practices in issues of infrastructure. The installation used geological survey technologies as interface 


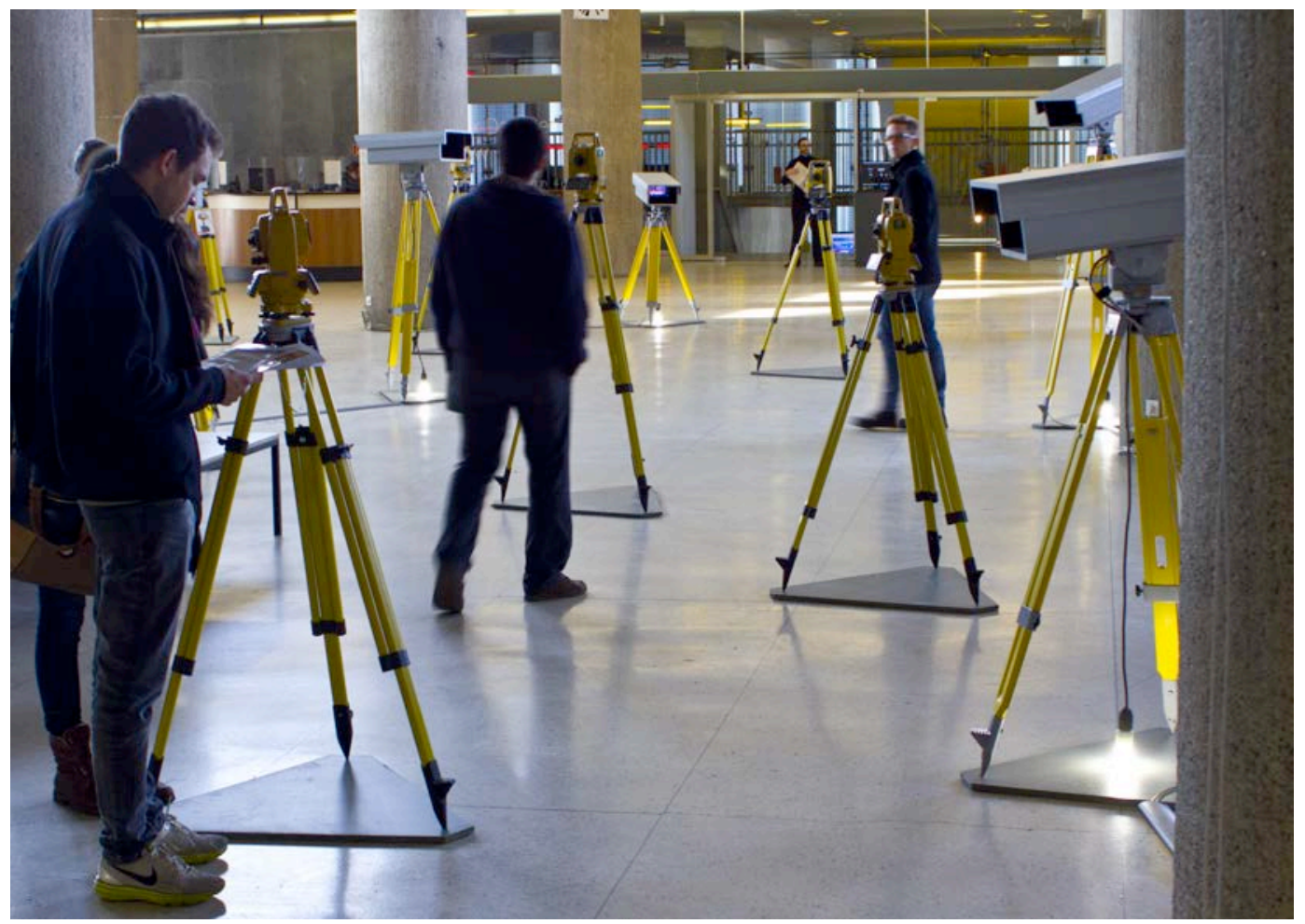

Figure 3: The geological survey of the data reality of the HKW space Allen and Gauthier's project from transmediale 2014. Image: Daniel Rakosi/transmediale/Critical Infrastructure-project, creative commons/used with permission

entry points to visualise and think about spatial or architectural settings through their data. This approach mixed geological machinery with big data themes to address how the institutional space of HKW became a data space of interactions. It also alluded to the geology of surveillance of past years' intensive discussion around the National Security Agency (NSA) and related activities.

In Allen and Gauthier's words:

CRITICAL INFRASTRUCTURE is perhaps less what lies after (in time), and more what lies beneath or has always been behind (in space, or matter). Technological infrastructures, as complex systems of materials enabling much of the interactions and aesthetics which enter the sensory milieu, have been stripped of their apparent and affective repercussions, and so have effectively (and incorrectly) been wrought as unimportant, depoliticised and uninteresting: 'You wouldn't be interested.' And so CRITICAL INFRASTRUCTURE hopes for views of this subterranean 
landscape, in the language that Homeland Security uses to describe sociotechnical assets that are 'so vital that their incapacity or destruction would have a debilitating effect on the defense or economic security' of nation states. $^{58}$

Allen and Gauthier's perspective analyses the infrastructure that both sustains the digital and is constantly temporally performed despite its nature as something that withdraws from active, perceived relation with its users. It is an infrastructural continuation of Smithson's abstract geology in how it sees technical and data relations condition both the geological and modes of thinking about the geological. It works to address the cognitive and cultural and the geological through media and informational layers. Indeed, Critical Infrastructures refers to the need to be able to talk about levels of material reality that at times withdraw from the reach of human agency and yet retain a sense of dynamic temporality; the layers of technological microtemporality and perception that cannot be reduced to the phenomenologically experientiable. ${ }^{59}$ Referring not merely to the work of media theorists but also to critical analysts of infrastructure such as Susan Leigh Star, Allen sketches the defining features of infrastructure in the context of experimental media design practice.

In other words, infrastructures are:

- embedded, but give themselves to experience as secreted access points

- transparent in terms of how we use them, but opaque in terms of how they work

- articulated at human scale but operational only at much larger and smaller scales

- material and systemic, as well as learned and practiced

- locally articulated, but rely on a globally 'installed base'

- designed to be reliable and established, but existentially insecure, unpredictable and precarious. ${ }^{6}$

Where this definition speaks directly to issues of design-something recently addressed also by Keller Easterling in terms of new governmental territories of infrastructural global space ${ }^{61}$-it also relates to the geo-aesthetic vocabulary, relevant to this article, and its task of creating new materialist aesthetics through technological art practices. In other words, in their project Allen and Gauthier also 
situate this this bundle of aesthetico-ethical issues directly in the discussions concerning post-digital aesthetics. Here, the post-digital becomes less a marker of what comes after the digital than a realisation of the overall influence of digital technologies as structural, infrastructural and epistemological contexts in which one is increasingly able to historicise the digital instead of succumbing to its ubiquity. This idea, most clearly articulated by Florian Cramer, becomes a way out of the term that might in itself be unsatisfactory and yet refer to a range of practices that move the discussion of digital aesthetics toward wider logistic and infrastructural material layers. In Cramer's much referenced take, he emphasises the fruitful range of cultural practices that move away from the hype of new media, repurpose analog technologies as sort of new media and produce hybrid sets which problematise what can be justifiably deemed new and old: 'zines that become anti-blogs or non-blogs, vinyl as anti-CD, cassette tapes as anti-MP3, analog film as anti-video'.62 As Cramer notes, and as becomes mobilised fully in Allen and Gauthier's work, such projects do not necessarily remain isolated instances of how the inflated hype of the digital and the creative can overwhelm. Rather, they can be perceived as investigating a relation to the perceived systemic/cybernetic power of infrastructures where a sense of agency is replaced easily with a cynicism about the overarching reach of surveilling and controlling infrastructures. ${ }^{63}$

It is this aspect that is of interest as a way to continue the earlier mentioned material-aesthetic practices into a contact point again with themes usually coined political. Already in Howse, Kemp and Jordan's take the geological relates to the logistical networks of computational culture production: the devices which demand a supply of minerals and earth materials to sustain the current political economic structure of computing. The post-digital is also the proto-digital of oscillators, diodes, logic gates, minerals and other elements that enable computationality to exist. ${ }^{64}$ In Allen's take, the post-digital minerality becomes an aesthetic figure, as well as a literal link, for artistic-research interventions into the produced, infrastructure habituality that connects the interfacial to the infrastructural:

Looking at the post-digital as infra-digital (below-digital, sub-digital), outlines a superorganism. It is an image of the technical that intends to take account of specific contexts and micro-relations of both creation and use. A post-digital minerality, or elementality shows the desire, the need, 
to bring the digital euphoria that erupted twenty years ago down to size, down to protocol, down to implementation, down to its gritty, grimy details. ${ }^{65}$

Here the mineral, and the use of other geological concepts, does not necessarily refer to the substance of the earth as the one and only defining context or ground of infrastructures, despite the temptation to see the underground defining the cultural; reminiscent of a Marxist perspective on base and superstructure. Instead, one could see that Allen's words and his project with Gauthier subtly respond to the idea of abstract geology in the sense of becoming a mode of describing relations of how certain actions, habits and patterns are sustained.

For sure, Smithson's take on abstract geology as a sort of 'Triassic politics'66 cuts to a different temporal level, one that refrains from direct relation to issues such as political economy or subjectivity that are usually deemed political. The recent media art perspectives brought to geological post-digital aesthetics are more keen to cut across temporal levels and see how even long-term durations are mobilised in relation to institutions of power. And yet, the idea of the geological persisting as one way to make sense of the material as dynamic, bent to practices of governmentality, design practices and more, is a way of ensuring that the layered view of contemporary technology infrastructures remains in the sights of political analysis.

In media theory, Kittler's media materialist take on software seems to display a similar ontological preference. In 'There is no Software', Kittler suggests a reverse engineering, or a genealogical record of the non-existence of software prescribed in the multiple layers that are needed to sustain software. Kittler returned the idea of 'archaeology' to computational hierarchies in a way that seemed implicitly to address issues of governmentality. But this emphasis was, always, more implicit even if one could claim that from the perspective of governance, the reality of software abstractions could not be more significant. Major aspects of code, operating systems and interfaces in general, as the places where subjectivity is produced, hangs on the issue of software abstractions. ${ }^{67}$ In Kittler's words:

this kind of descent from software to hardware, from higher to lower levels of observation, could be continued over more and more decades. All code operations, despite their metaphoric faculties such as 'call' or 'return', 
come down to absolutely local string manipulations and that is, I am afraid, to signifiers of voltage differences. 68

What the various artistic projects of geological vocabularies, of earth works and mineral ontologies refer to is indeed both a post-digital aesthetics, if understood in the sense of investigating the transversal depth of the infrastructural, and the radical continuation of a media materialist claim about the double bind of abstraction and materiality. Kittler's claims could be continued further, deep 'down', to include geological materialities, mineral durations and the wider sense in which it takes a planetary aesthetics to ensure computational culture. Benjamin Bratton's The Stack responds to this from the perspective of geopolitics and sovereignty, and aesthetic projects such as this expand a sense of materiality of the technological to discuss non-organic dimensions too. 69

\section{-CONCLUSIONS}

To conclude, this article has aimed to demonstrate how certain media art practices engage in complementary new materialist aesthetics that work in parallel to more philosophical projects such as those of Massumi, Grosz and Braidotti. The careful ontological work that addresses the lived abstraction (Massumi) and radical material temporalities (Grosz) shows a way out of accounts of corporeality focused on the (individual or species) body towards the wider atmospheres of life which include the inorganic too. Even discussions of the posthuman as articulated by Braidotti provide ways to actually talk of much more than just the posthuman; the expanded sense of the term is less focused on the human than on 'complex singularities' with multiple scales of reference far beyond the human-social.70 Braidotti insists on recognising the role women's, gender and queer studies, alongside postcolonial studies, have played in developing radical epistemologies of historical situations where the human has been negotiated in relation to the nonhuman-in institutions with specific gender and sexual biases, in colonial practices, and so on. ${ }^{71}$ It is by way of radical epistemologies as much as radical art practices and aesthetic notions that we can develop ways to grasp the sense of how the posthuman actually entails a larger transversal line that can also be carved out in terms of its geological, geographical and geophysical forces. And we must not 
forget how these fields of knowledge and matter are embedded in power, even if ideology is not the best word for this sort of exercise of power.

Jussi Parikka is Professor of Technological Culture and Aesthetics at the Winchester School of Art, University of Southampton. He is the author of the media ecology trilogy Digital Contagions (2007), Insect Media (2010) and, most recently, A Geology of Media (2015). He has also written widely on media archaeology, including What is Media Archaeology? (2012) and Media Archaeology: Approaches, Applications and Implications (2011, co-edited with Erkki Huhtamo). His collection, co-edited with Joasia Krysa, on the Finnish media art pioneer Erkki Kurenniemi will be published by MIT Press in 2015.

\section{-ACKNOWLEDGEMENTS}

A thank you to the anonymous peer reviewers, the editors of the issue and Jamie Allen for helpful feedback in revising the text.

-NOTES

${ }^{1}$ Michel Serres, The Natural Contract, trans. Elizabeth MacArthur and William Paulson, University of Michigan Press, Ann Arbor, 1995, p. 39.

2 Brian Massumi, What Animals Teach Us About Politics, Duke University Press, Durham, 2014, p. 92.

3 This has an interesting connection to the way contemporary digital theory and art often either relates to the binary as its main reference point or focuses on the spectrum. This article won't be able to address this question but it is inherent in some of the art practices addressed in the text that pertain to thinking about contemporary digital culture through its material spectra. A warm thanks for Jamie Allen for pointing out this aspect of contemporary theory and art of the digital culture.

${ }^{4}$ Judith Butler quoted in Massumi, What Animals Teach Us About Politics, p. 93.

${ }^{5}$ Rosi Braidotti, The Posthuman, Polity, Cambridge, 2013, pp. 94-5.

${ }^{6}$ See Rosi Braidotti and Timotheus Vermeulen, 'Borrowed Energy: A Conversation', Frieze, no. 165,

September 2014, <http://www.frieze.com/issue/article/borrowed-energy/>.

7 Braidotti, The Posthuman, p. 189.

8 In Transpositions, Braidotti speaks of zoe as the complementary side to the discursive bios of biopolitics: 'the other face of bios, that is to say zoe, the generative vitality of non- or pre-human or 
animal life'. It is through this reading of the zoe that the intensive non-discursive material side of the subjectivity pertinent to a post-human life is summoned. It is not that Braidotti claims to have been the sole discoverer of zoe but she is able to demonstrate the radical difference to, for example, Giorgio Agamben's more Heidegger-inspired accounts that read zoe through the bare life, and situate it in a more thanatological context that does not adequately theorise its vital life-something that actually comes close to Massumi's way of addressing the more-than-human, Rosi Braidotti, Transpositions: On Nomadic Ethics, Polity, Cambridge, 2006, pp. 37, 39.

${ }^{9}$ Massumi, What Animals Teach Us About Politics, p. 48.

10 Whitehead quoted in Brian Massumi, Semblance and Event: Activist Philosophy and the Occurrent Arts, MIT Press, Cambridge, MA, 2011, p. 28.

11 Jane Bennett, Vibrant Matter: A Political Ecology of Things, Duke University Press, Durham and London, 2010. Braidotti, The Posthuman.

12 Of course, one has to be aware of how in certain speculative versions, as Shaviro elaborates, the notion of 'feeling' refers not only to human but also to nonhuman and even nonorganic experience. This expanded sense of feeling comes out in Whitehead's work. See Steven Shaviro, The Universe of Things: On Speculative Realism, University of Minnesota Press, Minneapolis, 2014.

13 Mitchell Whitelaw, 'Sheer Hardware: Material Computing in the Work of Martin Howse and Ralf Baecker', Scan: Journal of Media Arts, vol. 10, no. 2, 2013,

<http://scan.net.au/scn/journal/vol10number2/Mitchell-Whitelaw.html>.

14 Donna Haraway, 'Anthropocene, Capitalocene, Chthulucene: Staying with the Trouble', 9 May 2014, online talk, <http://vimeo.com/97663518>.

15 Prominent examples include the massive Haus der Kulturen der Welt Anthropocene project, <http://www.hkw.de/en/programm/projekte/2014/anthropozaen/anthropozaen_2013_2014.php>, that ran for over two years in 2013 and 2014 with symposia, talks, exhibitions, publications and significant general public visibility. Similar art shows were curated in Hague and, for example, New York ('Dark Optimism'). See Eleanor Heartney, 'Art for the Anthropocene', Art in America, February 2014, <http://www.artinamericamagazine.com/news-features/magazine/art-for-the-anthropoceneera/>.

16 Personal communication to the author from Jamie Allen, email dated 20 February 2015. See 'Sustainability' Eyebeam <http://eyebeam.org/research/sustainability> and the Sustainability Road Show, <http://www.fact.co.uk/projects/climate-for-change/sustainability-road-show.aspx>. See also, for example, such projects as 'The Real Costs' project <http://www.therealcosts.com/> and Jamie Allen's 'Human Potential (Movement)' < http://www.jamieallen.com/human-potential-movement/>. 17 Allen, email dated 20 February 2015. Similarly various other conferences, such as Antropocene Feminism (April 2013) and After Extinction (April 2015) at the University of Wisconsin-Milwaukee Centre for 21st Century Studies and other events addressed the wider implications of this notion, which itself acts as a catalyst for a range of resonances across animal studies, posthumanism and, 
indeed, new materialism which is able to bring a conceptually more elaborated angle to the whole issue.

18 For recent work on land work and aesthetics, see the massive special issue of $O E I$ (in Swedish) on 'strata, geologisk tid, jordkonst/land art i Sverige', OEI, nos 63-4, 2014.

19 J. Zalasiewicz, et al., 'When did the Anthropocene Begin? A Mid-twentieth Century Boundary Level is Stratigraphically Optimal', Quaternary International, January 2015,

<http://dx.doi.org/10.1016/j.quaint.2014.11.045>.

20 Jean-Luc Nancy, The Ground of the Image, trans. Jeff Fort, Fordham University Press, New York, 2005.

21 See Gary Shapiro, Earthwards: Robert Smithson and Art after Babel, University of California Press, Berkeley, 1995.

22 Robert Smithson, 'A Sedimentation of the Mind: Earth Projects', in Robert Smithson: The Collected Writings, ed. Jack Flam, University of California Press, Berkeley, 1996 (1968), p. 105. See also how Simon O'Sullivan connects Smithson to a Deleuze-Guattarian inspired geo-aesthetics (around the concept of plane of immanence). Simon O'Sullivan, Art Encounters Deleuze and Guattari: Thought Beyond Representation, Palgrave Macmillan, Basingstoke, 2006, pp. 98-120.

23 Gregory Bateson, Steps to an Ecology of Mind, Paladin, St Albans, 1973.

${ }^{24}$ Smithson, 'A Sedimentation of the Mind', p. 101.

25 Ibid., p.107.

${ }^{26}$ Shapiro, Earthwards, p. 52

27 Smithson, 'A Sedimentation of the Mind', p. 112

28 Gilles Deleuze and Felix Guattari, A Thousand Plateaus, Continuum, London, 2004. Bennett, Vibrant Matter, p. 60.

29 Deleuze and Guattari, A Thousand Plateaus, p. 448.

30 Ibid., p. 451.

31 See Elizabeth Grosz, Becoming Undone: Darwinian Reflections on Life, Politics and Art, Duke University Press, Durham and London, 2011.

32 Ibid., p. 53.

33 The use of the notion of 'force' in this feminist new materialist context is not reducible to the traditional binary ways of considering it in terms of power/resistance, that is, identifiable opposites. Rather, force becomes a way of describing the wider complex assemblage of the situation. See Peta Hinton and Iris van der Tuin, 'Preface', Women: A Cultural Review, vol. 25, no. 1, 2014, pp.1-2.

34 "This "new" image of time is then one in which the past is coextensive with the present, which itself is coextensive with the future. This is an image of time in which the latter is no longer determined by movement.' O'Sullivan, p. 106.

35 This point of difference from a focus on code is well articulated by Whitelaw in 'Sheer Hardware: Material Computing in the Work of Martin Howse and Ralf Baecker'. 
${ }^{36}$ See Etienne Turpin, 'Robert Smithson's Abstract Geology: Revisiting the Premonitory Politics of the Triassic', in Elizabeth Ellsworth and Jamie Kruse (eds), Making the Geologic Now: Responses to the Material Conditions of Contemporary Life, Punctum, New York, 2013, pp. 173-8. Abstract geology is a notion that refers to the deterritorialisation of geology from the earth and its parallelism with the mind, with thinking. In ways that resonate with Bateson's ecology, abstract geology becomes a way of conceptualising thought as a planetary event:

The earth's surface and the figments of the mind have a way of disintegrating into discrete regions of art. Various agents, both fictional and real, somehow trade places with each otherone cannot avoid muddy thinking when it comes to earth projects, or what I will call 'abstract geology'. One's mind and the earth are in a constant state of erosion, mental rivers wear away abstract banks, brain waves undermine cliffs of thought, ideas decompose into stones of unknowing, and conceptual crystallisation break apart into deposits of gritty reason. Vast moving faculties occur in this geological miasma, and they move in the most physical way. This movement seems motionless, yet it crushes the landscape of logic under glacial reveries. This slow flowage makes one conscious of the turbidity of thinking. Slump, debris slides, avalanches all take place within the cracking limits of the brain. The entire body is pulled into the cerebral sediment, where particles and fragments make themselves known as solid consciousness. A bleached and fractured world surrounds the artist. To organise this mess of corrosion into patterns, grids, and subdivisions is an esthetic [sic] process that has scarcely been touched. Robert Smithson, The Collected Writings, ed. J. Flam, University of California Press, Berkeley, 1996, p. 100.

37 Thank you to Jamie Allen for highlighting for me the link between data mining and abstract geology.

38 Smithson, p. 134, quoted in Turpin, p. 174.

39 Turpin, p. 178.

40 Matthew Fuller, 'The Garden of Earthly Delights', Mute, 19 September 2012,

<http://www.metamute.org/editorial/articles/garden-earthly-delights>.

${ }^{41}$ In one way, such projects can be seen as responding to media theorist Friedrich Kittler's provocation of media ontology, which starts with silicon: 'Silicon is nature! Silicon is nature calculating itself. If you leave out the part of engineers who write little structures on silicon you see one part of matter calculating the rest of matter', Gane and Sale, 'Interview with Friedrich Kittler and Mark Hansen', Theory Culture \& Society, vol. 24, nos 7-8, 2007, p. 324. It also is a way of expanding the media arts and media archaeological discourse concerning 'deep time of the media' (as coined by Siegfried Zielinski) to a more literal understanding of the material aesthetics afforded by geology (as a science and as referring to planetary materialities). The theme of alternative deep time of the media is expanded in Jussi Parikka, A Geology of Media, University of Minnesota Press, Minneapolis, 2015.

42 Crystal World 2014, project Wiki, http://crystalworld.org.uk/wiki/doku.php last updated in 2014; accessed 3 December. 
43 See the Psychogeophysics wiki, <http://www.psychogeophysics.org/wiki/doku.php>. See also Parikka, A Geology of Media, pp. 59-82.

44 Martin Howse and Jonathan Kemp, 'Stack, Frame, Heap', Post-Media Lab, Leuphana University, 2013, $<$ http://postmedialab.org/jonathan-kemp-martin-howse>.

45 Martin Howse, 'the earthcodes project: substrate/shifting the site of execution',

<http://www.1010.co.uk/org/earthcode.html>. See also, Nadja Sayej, 'Programming Computers with Dirt: Earthboot Powers Computers with Geological Energy', Motherboard, 22 October 2013,

<http://motherboard.vice.com/blog/programming-computers-with-dirt-earthboot-powers-pcs-withgeological-energy>.

46 Sayej , 'Programming Computers with Dirt'.

47 Terike Haapoja, 'Inhale-Exhale', <http://www.terikehaapoja.net/inhale-exhale-2/>.

48 Manuel Delanda, 'Non-organic Life', in Incorporations, eds Jonathan Crary and Sanford Kwinter, Zone Books, New York, 1994, pp. 129-67.

${ }^{49}$ Pitch Drop, press release, September 2013, <http://sciencefriction.dk/a/wp-

content/uploads/2014/06/PITCH-DROP-ENGLISH-Press-Release-Sept-2013.pdf>.

50 On ethologies in a new materialist context see, for example, Braidotti's use of the term in

Transpositions. See also Jussi Parikka, Insect Media: An Archaeology of Animals and Technology,

University of Minnesota Press, Minneapolis, 2010, pp. 57-83.

51 Pitch Drop.

52 Jamie Allen to Jussi Parikka, 20 February 2015.

53 Ibid.

${ }^{54}$ Eric Alliez reads the onto-ethology of Deleuze and Guattari through Whitehead, in a way that also resonates in this context. Alliez's reading of Whitehead produces a sense of the transformed notion of the subject as superject, or even more effectively, in our context, a certain vector territory in which the various micro-brains of the world express themselves. In other words, it underlines that apperception does not return merely to the human subject and its faculties but involves a 'superior sensualism' and an 'experimental ontology' in which one should focus more tightly on the 'ontological auto-constitution of a new subject on the basis of its objects' than relations of object and subject. This even amounts, in Alliez's words, to a 'material meta-aesthetic'. This notion seems to draw on the idea of a single plane of composition that cuts across artificial borders of subjects, objects and categories. On the other hand, Whitehead's own philosophy draws on the wider sense of wordly micro-brains of perception and the need to not detach nature from aesthetic values; a theme that runs through Whitehead's philosophy is an argument against the bifurcation into the material and the cultural, the scientific and what we could name the hermeneutic. Eric Alliez, The Signature of the World: What is Deleuze and Guattari's Philosophy? Continuum, New York and London, 2004, pp. 56, 58. For a discussion of speculative realism, Whitehead and Kant, see Steven Shaviro, The Universe of Things.

55 Grosz, Becoming Undone, p. 28. 
56 Ibid., p. 30.

57 'Residency Project: Critical Infrastructure', <http://transmediale.de/resource/residency-project>.

58 Ibid.

${ }^{59}$ See in this context Mark Hansen's development of the notion of microtemporality as a way to understand how ubiquitous media culture of the twenty-first century works on levels that escape conscious experience, Mark Hansen, Feed-Forward. On the Future of Twenty-First-Century Media, University of Chicago Press, Chicago, 2014.

60 Jamie Allen, 'Critical Infrastructure', Post-Digital Research, Kunsthall Aarhus, 6 October 2013, $<$ http://post-digital.projects.cavi.dk/?p=356>.

${ }^{61}$ Keller Easterling, Extrastatecraft: The Power of Infrastructure Space, Verso, London, 2014.

62 Florian Cramer, 'What is Post-Digital?,' APRJA-A Peer Reviewed Journal About Post-Digital Research, vol. 3, no 1, 2014, <http://www.aprja.net/?p=1318>.

63 In Cramer's words: 'We could metaphorically describe post-digital cultures as postcolonial practices in a communications world taken over by a military-industrial complex made up of only a handful of global players', ibid.

64 Whitelaw, 'Sheer Hardware', referring to Ralf Baecker's Irrational Computing project.

65 Allen, 'Critical Infrastructure'.

66 Turpin, 'Robert Smithson's Abstract Geology: Revisiting the Premonitory Politics of the Triassic', p.

178. To quote Turpin: 'Smithson's preference for Triassic politics is an attempt to break with the limited horizon of European aesthetics and its concrescence in the form of Modernism criticism.'

${ }^{67}$ As Whitelaw demonstrates by discussing art projects by Howse and Ralf Baecker, the central issue of computation is related to the material independence of the symbolic code-an assumption that is, however, problematised in these projects, including Baecker's Irrational Computing. In Whitelaw's words: 'It is here that the material computing of Baecker and Howse peels away from Conrad (and Turing). One of the key attributes of the Turing model is its dependence on discrete, symbolic elements; in any real computing system these symbols must be carefully stored on and transcribed from material substrates in a messy, analog world. The independence of symbol and substrate is a crucial attribute of the digital-Will Schrimshaw (2012) describes it aptly as an 'indifference' to the material. Baecker and Howse show instead how the symbolic domain can be attuned to the flux of the material', Whitelaw, 'Sheer Hardware', np.

68 Friedrich Kittler, 'There is No Software', Ctheory, 18 October 1995,

$<$ http://www.ctheory.net/articles.aspx?id=74>.

${ }^{69}$ Benjamin Bratton, The Stack: Software and Sovereignty, MIT Press, Cambridge, MA, forthcoming 2015.

70 Braidotti, The Posthuman, p. 139.

71 Ibid., p. 148. 


\section{-BiBLIOGRAPHY}

Alliez, E. The Signature of the World: What is Deleuze and Guattari's Philosophy?, Continuum, New York and London, 2004.

Bateson, G., Steps to an Ecology of Mind, Paladin, St Albans, 1973.

Bennett, J., Vibrant Matter: A Political Ecology of Things, Duke University Press, Durham and London, 2010.

Braidotti, R., The Posthuman, Polity, Cambridge, 2013.

Braidotti, R., Transpositions: On Nomadic Ethics, Polity, Cambridge, 2006.

Braidotti, R. and T. Vermeulen, 'Borrowed Energy. A Conversation', Frieze, no. 165, September 2014, <http://www.frieze.com/issue/article/borrowed-energy/>.

Bratton, B., The Stack: Software and Sovereignty, MIT Press, Cambridge, MA, forthcoming 2015.

Cramer, F., 'What is Post-Digital?', APRJA-A Peer Reviewed Journal About Post-Digital Research, vol. 3, no. 1, 2014, <http://www.aprja.net/?p=1318>.

Crary, J. and S. Kwinter (eds), Incorporations, Zone Books, New York, 1994.

Delanda, M., 'Non-organic Life' in J. Crary and S. Kwinter (eds), Incorporations, Zone Books, New York, 1994.

Deleuze, G. and F. Guattari, A Thousand Plateaus, Continuum, London, 2004.

Easterling, K., Extrastatecraft: The Power of Infrastructure Space, Verso, London, 2014.

Ellsworth, E. and J. Kruse (eds), Making the Geologic Now: Responses to the Material Conditions of Contemporary Life, Punctum, New York, 2013.

Fuller, M. 'The Garden of Earthly Delights', Mute, 19 September 2012, <http://www.metamute.org/editorial/articles/garden-earthly-delights>.

Gane, N. and S. Sale, 'Interview with Friedrich Kittler and Mark Hansen', Theory Culture \& Society, vol. 24, nos 7-8, 2007. doi: http://dx.doi.org/10.1177/0263276407086401

Grosz, E., Becoming Undone: Darwinian Reflections on Life, Politics and Art, Duke University Press, Durham and London, 2011. doi: http://dx.doi.org/10.1215/9780822394433

Hansen, M., Feed-Forward: On the Future of Twenty-First-Century Media, University of Chicago Press, Chicago, 2014. doi: http://dx.doi.org/10.7208/chicago/9780226199863.001.0001

Haraway, D., 'Anthropocene, Capitalocene, Chthulucene: Staying with the Trouble', 9 May 2014, online talk, <http://vimeo.com/97663518?>.

Heartney, E., 'Art for the Anthropocene', Art in America, February 2014, $<$ http://www.artinamericamagazine.com/news-features/magazine/art-for-theanthropocene-era/>.

Hinton, P. and I. van der Tuin, 'Preface', Women: A Cultural Review, vol. 25, no. 1, 2014. doi: http://dx.doi.org/10.1080/09574042.2014.903781 
Howse, M. and J. Kemp, 'Stack, Frame, Heap', Post-media Lab, Leuphana University, 2013, <http://postmedialab.org/jonathan-kemp-martin-howse>.

Kittler, F., 'There is No Software', Ctheory, 18 October 1995, $<$ http://www.ctheory.net/articles.aspx?id=74>.

Massumi, B., What Animals Teach Us About Politics, Duke University Press, Durham, 2014. doi: http://dx.doi.org/10.1215/9780822376057 and doi: http://dx.doi.org/10.1215/9780822376057-001

Massumi, B., Semblance and Event: Activist Philosophy and the Occurrent Arts, MIT Press, Cambridge, MA, 2011.

Nancy, J-L., The Ground of the Image, trans. Jeff Fort, Fordham University Press, New York, 2005.

O'Sullivan, S., Art Encounters Deleuze and Guattari: Thought Beyond Representation, Palgrave Macmillan, Basingstoke, 2006.

Parikka, J., Insect Media: An Archaeology of Animals and Technology, University of Minnesota Press, Minneapolis, 2010.

Parikka, J., A Geology of Media, University of Minnesota Press, Minneapolis, 2015.

Sayej, N., 'Programming Computers with Dirt: Earthboot Powers Computers with Geological Energy', Motherboard, 22 October 2013, <http://motherboard.vice.com/blog/programmingcomputers-with-dirt-earthboot-powers-pcs-with-geological-energy>.

Serres, M., The Natural Contract, trans. Elizabeth MacArthur and William Paulson, University of Michigan Press, Ann Arbor, 1995.

Shapiro, G., Earthwards: Robert Smithson and Art after Babel, University of California Press, Berkeley, 1995.

Shaviro, S., The Universe of Things: On Speculative Realism, University of Minnesota Press, Minneapolis, 2014. doi: http://dx.doi.org/10.5749/minnesota/9780816689248.001.0001

Smithson, R., 'A Sedimentation of the Mind: Earth Projects', in J. Flam (ed.), Robert Smithson: The Collected Writings, University of California Press, Berkeley, 1996 (1968).

Turpin, E., 'Robert Smithson's Abstract Geology: Revisiting the Premonitory Politics of the Triassic', in E. Ellsworth and J. Kruse (eds), Making the Geologic Now: Responses to the Material Conditions of Contemporary Life, Punctum, New York, 2013.

Whitelaw, M., 'Sheer Hardware: Material Computing in the Work of Martin Howse and Ralf Baecker', Scan: Journal of Media Arts, vol. 10, no. 2, 2013, <http://scan.net.au/scn/journal/vol10number2/Mitchell-Whitelaw.html>.

Zalasiewicz, J., et al., 'When did the Anthropocene Begin? A Mid-twentieth Century Boundary Level is Stratigraphically Optimal', Quaternary International, January 2015, doi: http://dx.doi.org/10.1016/j.quaint.2014.11.045 